\title{
Analysis on Music Education in Regular Colleges and Its Diversified Thinking
}

\author{
$\mathrm{Xia} \mathrm{Wu}$ \\ Department of Music \\ Xiamen University Tan Kah Kee College \\ Xiamen, China
}

\begin{abstract}
Music is the most natural expression of human thoughts and emotions. Music education can stimulate people's creative thinking. However, the music education in regular colleges faces problems while achieving results and lags behind the global multicultural music education in development. It is distinctly important to innovate in teaching ideas and train high quality music teachers in the multicultural music education.
\end{abstract}

Keywords-multicultural music education; innovation; music teachers

\section{INTRODUCTION}

The music education in regular colleges serves as an important carrier of aesthetic education in quality-oriented education and has profound connotations.

Music is the most natural expression of human thoughts and emotions. As a comprehensive multifunctional discipline, it successfully stimulates people's music potential and makes life more interesting, thoughts more creative, work more effective and life more colorful. The music education in regular colleges is to train students' aesthetic and creative ability and promote their integrated development.

Kodaly Zoltan once said, "Music closely links to our life. We cannot live and our life is unsatisfactory without music. As an organic part of our daily life, music expresses our soul and meets our spiritual requirements". He addresses, "Music is the nourishment for the mind that cannot be replaced by other things. Without it, we will have barren spirit and unsound spiritual life". He frankly says, "Music is an indispensable part of human culture. Good music education can improve students' music ability and promote their development in other disciplines". The former Vice Premier of the State Council, Li Lanqing remarks, "Without music education, the national education will be incomplete and it is adverse to the improvement of people's quality". Music education embodies music quality and self-cultivation of a country, a nation and a society. It more concretely reflects artistic appreciation, spiritual appearance and life quality.

Music can arouse people's creative thinking. The course of music education enables college students to thoroughly get rid

Project: Humanity B Class Social Sciences Research Project of Education Department in Fujian, personal independent project Objective, Value and Subject Orientation of Music Education in Regular Colleges, project No.: JBS09007 Finished. of the stylized exam-oriented education. It transfers from single "intellectual education" to "music education" and "spiritual education". In this process, students enjoy the edification of music. It stimulates their creative spirit and practical skills, trains their emotional attitude towards art and ability of aesthetic judgment and lofty sentiments, laying solid foundation for integrated development.

Amazingly, the invention of great significance and the achievements of academic and scientific research of world famous scientists and Nobel Prize Winners come from imagery thinking and creativity. Music is an important way to enrich imagination. The information transmission of music sound wave has peculiar and new stimulation on human's creative thinking. The founder of relativity theory Einstein is an outstanding physicist as well as an excellent violinist; the founder of quantum theory Planck is a pianist; the famous geologist of our country Li Siguang is scientist and musician and creates the first violin piece in China; the famous scientist Qian Xuesen is renowned as "the Father of Missile" and has a colorful art world. The former Vice Primer of the State Council Li Lanqing has high attainments in researches on diversified music art. He thinks we should receive music education from childhood and proposes the measures to introduce elegant music in schools. It has positive and profound influences on the popularization, reform and innovation of music education in regular colleges.

Music education is the education of people. In this process, the objective is the education and training of people through music.

\section{Music EdUCATION IN DEVELOPMENT}

It clearly proposes in the Development Plan for Art Education in Schools issued by the Ministry of Education (2001-2010) that all colleges should provide artistic elective and limited optional courses and bring it in teaching plan and credit before 2005. Teaching reform of art courses is deepened and scientific research is strengthened to improve the teaching quality of art education.

\section{A. Gratifying Achievements}

Some colleges providing education of music art have obtained gratifying results in the more than ten years. It owes to attention from leaders, active participation, sound music 
education institutions, high level music teachers, reasonable distribution and implementation, complete software and hardware facilities, practical teaching contents and interestingness, multicultural music, diversified teaching forms, innovative teaching theory, rigorous subject setting, scientific teaching methods and the persistence of music education. College students are provided the innovative classroom to learn knowledge about music culture, the platform to show music talents and the comfortable environment to conduct social practice of music art. It deepens the reform and innovation of music teaching, improves college students' music accomplishment, knowledge attainments and practical ability in artistic creation.

In the education of music art, Tsinghua University and Peking University widely publicize the knowledge about music culture among students and obtain notable results. Nanjing University promotes work in all areas by drawing upon the experience gained on key points and embodies multicultural music. The college student symphony orchestra of this school goes abroad to play symphony with characteristics of excellent Chinese music culture and has received good reputation from foreign college students.

Art education is an important teaching content in North China University of Water Resources and Electric Power. Elective and limited optional courses like Vocal Music, Basic Music Theory and Chinese and Foreign Music History had been provided this school. Art teams like traditional instruments orchestra, dance team and Quyi team organized by students activate cultural life on campus, train college students' integrated ability and quality. Music pieces created by students of this school win national prize for seven times and provincial and ministerial awards for sixteen times.

University Students Arts Festival held by the Ministry of Education arouses the enthusiasm of teachers and students and promotes the diversified reform and innovation of music education.

In recent years, supported by the Ministry of Education and the Ministry of Culture, National Dance Theater, National Symphony Orchestra and National Peking Opera Theater play in colleges and give lectures on music drama, contributing to students' acceptance and pursuit of elegant art.

\section{B. Existence of Gaps}

When most colleges make achievements in music education, influenced by uncertain factors like region and teachers, some colleges are at the initial stage in the development of music education. The existing music education lags behind. Furthermore, some colleges use music education to deal with superior competent departments. We should pay special attention to and reflect on it.

\section{Multicultural Music EducAtion, the IMPERAtive DEVELOPMENT TENDENCY}

In the late twentieth century, the multicultural music education appears in western countries. In Seminar Decision on Future and Action of National Association for Music Education of America in 1990, the music education has transferred from self-development, self-improvement and selfdigestion based on local music culture to multicultural music education. It emphasizes in National Standard of Art Education of America that students should "understand world music". The World Congress of International Society for Music Education clearly proposes the new direction of pluralistic development of music education with "sharing of the world's music" as the theme. Public elective course of world music is provided for American college students to lay a solid foundation for the training of their attainments of music culture and multicultural musical ability. It is an essential condition for graduates of music major to serve as music teachers. It defines in National Standard of Art Education "Education is incomplete without art". In order to train "allround" college students, more than one thousand American colleges establish school of music. All schools in league of famous universities establish department of music. All colleges establish institutions of music education for students to take music as an elective course.

Although the music education in Britain centers on traditional European classical education, it also pays high attention to the world's multicultural music. Universities in Britain integrate courses of music education in other disciplines and achieve good results; colleges in Japan take music in additional examination which includes in the credit; almost all colleges in Russia have advanced system of music education, first-class teaching equipment and high level music teachers; as the center of music in Europe, Germany has focused on multicultural music education at the beginning of the 21 st century.

Under the background of knowledge globalization, the music education in our country overcomes the restriction of single music culture and becomes multicultural with Chinese characteristics, in order to develop educational business and train all-round talents of the 21 st century. It has become an inevitable trend to develop multicultural music education in the new period which can manifest cultural value and orientation. The multicultural music education in colleges is multilevel and comprehensive education. It has become an urgent affair to keep pace with the times to innovate in teaching ideas.

\section{A. Development Direction of Music Education}

Multicultural music education is an important strategy to promote the development of China's education. The establishment of concept of "music globalization" and integration of excellent Chinese music culture with classical music culture of the world help students to understand national styles and cultural traditions of different countries, different characteristics of music culture formed under different social backgrounds as well as values, artistic view, belief, life attitudes and behavioral patterns. They compare, appreciate and analyze, learn from others' strong points and make foreign things serve China, in order to integrate the music and cultural education of China with that in western and non-western countries and make the quintessence of it more complete, extensive and colorful. The multicultural music education makes for students to communicate with people from all over the world, deepens their understanding of music culture and 
broadens their horizons in cultural knowledge. Furthermore, it enriches their cultural connotation and trains broad and profound mind, so that they can respect and learn excellent cultures worldwide more equally, love our traditional national culture and our country more deeply, establish correct outlook on life, world outlook and values and artistic view. Friendly exchanges with people around the world will be strengthened to promote the healthy, civilized and harmonious development of human society.

\section{B. Teaching Practice}

Independent sound systems in teaching contents, course provision, teaching equipment and construction of teachers' team as well as management must be established to implement multicultural music education. As a teaching art, multicultural music education is a science that music course combines with teaching art most closely. In order to innovate in music teaching, we must know about music information and cultural information, teaching trends at home and abroad and have forward-looking teaching ideas. Teachers should consider the nature of music and use scientific educational methods to yield twice the result with half the effort.

\section{Music Teacher - the Key to Multicultural Music Education}

Music teachers with high quality are crucial to successful multicultural music education. The professional ethics, comprehensive quality and cultural quality of music teachers must be strengthened to meet the requirements of multicultural music education in the 21 st century.

1) Professional ethics: Music education is a sacred cause. Music teachers should be a model of virtue for students and teach by personal example as well as verbal instruction. They should enlighten and stimulate students to research, discuss and operate and move them with true feelings, becoming good teachers and helpful friends.

2) Comprehensive quality: In multicultural music education, music teachers are leaders and planners. They should use "teaching art" and heuristic, interactive and visual teaching pattern to integrate the true essence of music education in teaching, make the obscure, rigid, boring and abstract teaching active for students to accept easily.

The artistic practice of music education is a vital part of multicultural music education. Teachers can organize students to participate in artistic practice of music so that they show comprehensive music skills, enrich music knowledge and artistic skills and improve comprehensive quality. Meanwhile, it can train students' comprehensive skills and teamwork spirit.

Music teachers should take the lead in creative teaching, explore boldly and change teaching patterns and integrate the world's classical music culture in teaching of traditional Chinese music culture and carry out "two-in-one" comparable and reference teaching, guiding students to discover, imagine, explore and create. Innovative thinking goes through the whole teaching process and form student-oriented new type teaching pattern of multicultural music education, in order to improve students' creative thinking and all-round learning ability. In multicultural music education, teachers should encourage college students to excel them.

3) Cultural quality: Music teachers must study further and make progress continuously through learning constantly updated frontier idea of music education. They should participate in course provision of multicultural music education and academic research, compile teaching contents and grasp modern teaching means and research students' psychology. Meanwhile, they can make all-out efforts to carry forward excellent Chinese music culture and integrate it in the world's classical music culture and teach the world's advanced music education, in order to realize the globalization of music education.

\section{CONCLUSION}

With the soaring development of multicultural music education in the world, the music education in regular colleges of our country should keep up with the world's advanced teaching pattern of music education, continuously absorb quintessence of multicultural music education in the world and construct teaching system of multicultural music education with Chinese national characteristics, in order to deepen the multicultural music education and train high quality college students. In this way, it can further promote the implementation of knowledge globalization, the integration of Chinese music culture in the world and the world's music culture in China as well as the integration and development of the world's multicultural music education.

\section{REFERENCES}

[1] Shen Zhilong. Music Education in MIT and Enlightenment, China Music Education, the third issue in 1998

[2] Zhou Qixun. Comparison and Reference of Thoughts and Objectives in Music Education at Home and Abroad in the Twentieth Century, Arts Exploration, the sixth issue in 2001

[3] Li Lanqing. Music and Life-Lecture on Music Sketches, Dec.28, 2004

[4] Guo Shengjian. Investigation Report on American Music Education, Hunan Normal University Press, the first edition in Nov.2008 